\title{
Outcome at hospital discharge of patients admitted to the ICU. analysis of a prospective cohorts from a polyvalent icu in an university hospital
}

\author{
D Arias-Verdú*, M Delgado-Amaya, G Seller-Pérez, E Banderas-Bravo, J Barrueco-Francioni, M Herrera-Gutierrez \\ From ESICM LIVES 2015 \\ Berlin, Germany. 3-7 October 2015
}

\section{Objectives}

To define the outcome at hospital discharge of our patients and detect possible variables differentiating mortality intra-ICU and after ICI-discharge.

\section{Methods}

Preliminary results from a prospective cohorts study over all patients admitted to our unit for one year excluding coronary patients and those with a stay of less that 24 hours. The Ethics Committee from our centre approved this work. Data as mean (standard error for mean). We applied a logistic regression methodology. Results as OR (95\% CI).

\section{Results}

962 patients. Admitted from emergencies dept. 28\%, hospital wards $23,9 \%$, surgical theatre $38,2 \%$ (9,3\% urgent $y$ $28,9 \%$ elective) y $10 \%$ from other centres. $38,1 \%$ had been admitted to the hospital at least once the previous year and $5,6 \%$ in the ICU. Hospital stay previous to ICU admission was $5,9(0,36)$ days $[5,26(0,32)$ in survivors, $8,42(1,13)$ in deaths, $\mathrm{p}<0,001]$.

Total mortality was $23 \%, 18,1 \%$ during UCI stay and the rest after discharge (3,7\% in ICU readmission and $1,1 \%$ in ward). Among 41 cases with a DNR order, $31,7 \%$ was discharged alive from the hospital.

Age (OR 1,01, 1-1,02), previous cerebral vascular disease $(3,8, \mathrm{q}, 8-8,1$, immunosuppression $(1,8,1,2-2,8)$ and SOFA at admission $(1,3,1,2-1,4)$, mechanical ventilation $(5,2,2,7-$ $9,7)$, vasopressors $(1,8,1,2-2,7)$, SOFA $>6(2,3,1,4-3,3)$ or AKI $(3,4,2,3-5,4)$ were related to mortality.

When focusing in mortality after ICU discharge, male gender (OR 2,6, IC 1,1-6,2), admission from a medical ward (OR 9,0, IC 3,2-25,6), hospital stay before admission (OR 1,03, IC 1,01-1,05), AKI (OR 3,1, IC 1,1-8,2) and Sabadell score (Grade I, OR 10,6:3,3-33,9; II 27,4:7,8-96,5; III 130,9:32,1-534,2) showed relationship.

\section{Conclusions}

Among our patients DNR order status was registered in a low number of cases and a third of those with a DNR order were discharged alive from the hospital.

The Sabadell Score is a useful tool for predicting hospital mortality in those patients discharged from the ICU.

Published: 1 October 2015

doi:10.1186/2197-425X-3-S1-A964

Cite this article as: Arias-Verdú et al:: Outcome at hospital discharge of patients admitted to the ICU. analysis of a prospective cohorts from a polyvalent icu in an university hospital. Intensive Care Medicine Experimental 2015 3(Suppl 1):A964

Submit your manuscript to a SpringerOpen ${ }^{\odot}$ journal and benefit from:

- Convenient online submission

- Rigorous peer review

- Immediate publication on acceptance

- Open access: articles freely available online

- High visibility within the field

- Retaining the copyright to your article

Submit your next manuscript at $>$ springeropen.com

Complejo Universitario Carlos Haya, Malaga, Spain 